\title{
Effect of Bio-fertilizers on Growth and Yield of Garlic (Allium sativum Linn.)
}

\section{Chandra Bhushan ${ }^{1,4}$, Anil Kumar Yadav², Hemant Kumar Gangwar 3 , Brajesh Kumar", Sunil Kumar Katiyar ${ }^{4}$ and Nitin Vikram ${ }^{*}$}

\author{
${ }^{1}$ Department of Horticulture, Janta College, Bakewar, Etawah, India \\ ${ }^{2}$ Department of Horticulture, Sardar Vallabh Bhai Patel University of Agriculture and \\ Technology, Modipuram, Meerut, India \\ ${ }^{3}$ Department of Agronomy, Narendra Deo University of Agriculture and Technology, \\ Kumarganj, Ayodhya, India \\ ${ }^{4}$ Zila Parishad Krishi Mahavidyalaya, Banda, India \\ *Corresponding author
}

\section{A B S T R A C T}

K e y w o r d s
Garlic; Biofertilizer,
Azotobactor,
Phosphorus
Solubilizing
Bacteria, Vasicular
Arbuscular
Mycorrhiza

An investigation on the project entitled "Effect of bio-fertilizers on growth and yield of garlic (Allium sativum Linn.)" was taken up in the Horticultural Garden of Janta College, Bakewar, Etawah, U.P. which falls under sub-tropical climatic region during 2011-12 to work-out the optimum dose of the three bio-fertilizer and their combination on garlic variety-G1. Fourteen treatments namely, a control receiving FYM as basal dose @ 20 ton/ha + RDF (100:50:50) $\left(\mathrm{T}_{0}\right)$, Azotobactor $6 \mathrm{~kg} / \mathrm{ha}\left(\mathrm{T}_{1}\right)$, Azotobactor $8 \mathrm{~kg} / \mathrm{ha}\left(\mathrm{T}_{2}\right)$, PSB 6 $\mathrm{kg} / \mathrm{ha}\left(\mathrm{T}_{3}\right)$, PSB $8 \mathrm{~kg} / \mathrm{ha}\left(\mathrm{T}_{4}\right)$, VAM $6 \mathrm{~kg} / \mathrm{ha}\left(\mathrm{T}_{5}\right)$, VAM $8 \mathrm{~kg} / \mathrm{ha}\left(\mathrm{T}_{6}\right)$, Azotobactor $6 \mathrm{~kg} / \mathrm{ha}$ + PSB $6 \mathrm{~kg} / \mathrm{ha}+\mathrm{VAM} 6 \mathrm{~kg} / \mathrm{ha}\left(\mathrm{T}_{7}\right)$, Azotobactor $6 \mathrm{~kg} / \mathrm{ha}+\mathrm{PSB} 8 \mathrm{~kg} / \mathrm{ha}+\mathrm{VAM} 8 \mathrm{~kg} / \mathrm{ha}$ $\left(\mathrm{T}_{8}\right)$, Azotobactor $6 \mathrm{~kg} / \mathrm{ha}+\mathrm{PSB} 6 \mathrm{~kg} / \mathrm{ha}+\mathrm{VAM} 8 \mathrm{~kg} / \mathrm{ha}\left(\mathrm{T}_{9}\right)$, Azotobactor $6 \mathrm{~kg} / \mathrm{ha}+\mathrm{PSB}$ $8 \mathrm{~kg} / \mathrm{ha}+\mathrm{VAM} 6 \mathrm{~kg} / \mathrm{ha}\left(\mathrm{T}_{10}\right)$, Azotobactor $8 \mathrm{~kg} / \mathrm{ha}+\mathrm{PSB} 6 \mathrm{~kg} / \mathrm{ha}+\mathrm{VAM} 6 \mathrm{~kg} / \mathrm{ha}\left(\mathrm{T}_{11}\right)$, Azotobactor $8 \mathrm{~kg} / \mathrm{ha}+$ PSB $8 \mathrm{~kg} / \mathrm{ha}+\mathrm{VAM} 8 \mathrm{~kg} / \mathrm{ha}\left(\mathrm{T}_{12}\right)$, Azotobactor $8 \mathrm{~kg} / \mathrm{ha}+\mathrm{PSB} 6$ $\mathrm{kg} / \mathrm{ha}+\mathrm{VAM} 8 \mathrm{~kg} / \mathrm{ha}\left(\mathrm{T}_{13}\right)$, Azotobactor $8 \mathrm{~kg} / \mathrm{ha}+\mathrm{PSB} 8 \mathrm{~kg} / \mathrm{ha}+\mathrm{VAM} 6 \mathrm{~kg} / \mathrm{ha}\left(\mathrm{T}_{14}\right)$ applied into soil prior to transplanting of seed cloves. The experiment was carried out in Randomized Block Design with 3 replications having plot size 3 sq.mt. The combination of treatments namely Azotobactor $8 \mathrm{~kg} / \mathrm{ha}+\mathrm{PSB} 8 \mathrm{~kg} / \mathrm{ha}+\mathrm{VAM} 8 \mathrm{~kg} / \mathrm{ha}\left(\mathrm{T}_{12}\right)$ resulted the best optimal doze for garlic giving average plant height $79.83 \mathrm{~cm}$, average number of leaves 9.86, average diameter of pseudo stem $1.13 \mathrm{~cm}$, average weight of bulb $38.03 \mathrm{~g}$ and $5.96 \mathrm{~kg}$ average yield per plot are better for yield and profit at less cost.

\section{Introduction}

Garlic is the second most widely cultivated bulb crop, after onion, and has long been recognized as a valuable spice and condiment throughout India. In India garlic is grown an area of 274000 hectares with a production of 1271000 MT. Garlic possesses highly nutritive value and it has been considered as a rich source of carbohydrates, proteins and 
phosphorus. Ascorbic acid content was also reported to be very high in green garlic (Pradhan et al., 1977).Uninjured bulb contains a colourless, odourless water soluble amino acid called "Allin" which, after crushing converts into "Allicin" whose principal ingredient is odoriferous diallyldisulphide. Garlic contains $0-1 \%$ volatile oil, whose chief constituents are diallyldisulphide (60\%), allyl alcohol (5.4\%), dimethyl trisulphide (2-4\%), methyl allyltrisulphide (1.5\%), methyl allyldisulphide (1.2\%) and diallyltrisulphide (1\%) (Satish and Rajangam, 2011).Garlic has some antifungal, antimicrobial, insecticidal and other medicinal properties. It has hypoglycemic properties. Garlic therapy has also been suggested in flatulence, constipation, faulty digestion, inadequate food intake, leprosy, chronic coughs and many other diseases (Adegoke et $a l ., 1998)$. It is grown widely in the country and the state of U.P. and to boost up it's per hectare yield the farmers resort to use of inorganic fertilizers containing $\mathrm{N}, \mathrm{P}$ and $\mathrm{K}$. But use of inorganic fertilizers to obtain higher yield with quality produce is not only costly but also a precursor of health hazards by polluting the environment, soil and water. This anxiety has now led them to devise ways and means to switch over the use of ecofriendly biofertilizers in crop production. Azotobacter and PSB fix atmospheric nitrogen and solubilise phosphorous to increase soil fertility and biological activities. Biofertilizers are products having living cells of different types of micro-organism, which have an ability to convert nutritionally important elements and also, bio-fertilizers are known to play principle role in expanding availability of $\mathrm{N}$. and $\mathrm{P}$. besides improving biological fixation of atmospheric nitrogen and build hormones and anti-metabolites (Bhat et al., 2013). Availability of nitrogen is important for growing plants. It is a main constituent of protein and nucleic acid molecules. It is also a part of chlorophyll molecules. Phosphorus is vital constituent of phospholipids, nucleic acids and several enzymes. It is also needed for the transfer of energy within the plant system and is involved in its various metabolic activities. Phosphorus has its beneficial effect on early root development, plant growth, yield and quality (Verma, 1993). Potassium plays anindispensable role in plant metabolism such as photosynthesis, translocation of food, regulation of plant pores, activation of plant catalyst and resistance against pests and diseases. Potassium improves colour, glossiness and dry matter accumulation besides improving keeping quality of the crop (Dorais et al., 2001). Therefore, keeping in view the above facts in mind, an attempt has been made in the present investigation to study the effect of biofertilizers on growth and yield of garlic.

\section{Materials and Methods}

The experiment was conducted at on the experimental farm of Department of Horticulture of Janta College, Bakewar, Etawah, during rabi season of the year 20112012. Etawah falls in the southwestern portion of Uttar Pradesh, between the parallels of $26.21^{\circ}$ and $27.1^{\circ}$ North latitude and $78.45^{\circ}$ and $79.45^{\circ}$ East longitude, at the elevation of $150.06 \mathrm{~m}$ above the mean sea levelin the gangetic plane of central U.P. Average rainfall of Etawah ranges from 805 $\mathrm{mm}$. per annum. The soil of the experimental field was sandy loam, $\mathrm{pH} 6.6$ and loam in texture, normal in reaction with medium in respect to nitrogen, phosphorus and potassium. The experiment consisting of 15 treatments viz., two levels of Azotobactor (6 and $8 \mathrm{~kg}$ ), two level of P.S.B. (6 and $8 \mathrm{~kg}$ ) and two levels of VAM (6 and $8 \mathrm{~kg}$ ), Eight combinations of Azotobactor, PSB and VAM with doses and one is absolute control (N:P:K =100:50:50) was laid out in simple $\mathrm{RBD}$ with three replications. 


\section{Results and Discussion}

Application of 3 biofertilizers, viz., Azotobactor, PSB and VAM each @ 6 kg and $8 \mathrm{~kg}$ per hectare applied separately or in combination was either at par with control or were very less effective. The plant height was observed to be significantly affected by the treatment. The height noted in control plants was $73.36 \mathrm{~cm}$, whereas it was noted significantly maximum observed in T12 (79.83 cm.) (Gaiki et al., 2006, Talware et al., 2012 and Singh et al., 2017). In rest of the treatments it ranged between $73.83 \mathrm{~cm}$. to $78.93 \mathrm{~cm}$. Average no. of leaves as recorded in control was 6.30. It was significantly enhanced up to 9.86 in T12 (Talware et al., 2012and Singh et al., 2017). In rest of treatments it ranged between 6.40 to 9.56 .
Average diameter of pseudostem in control plants was recorded minimum $(0.66 \mathrm{~cm})$. It was significantly increased to the maximum in T12 $(1.13 \mathrm{~cm})$ (Bhandari et al., 2014 and Das et al., 2014). The Average diameter of pseudostem in other treatments ranged from $0.70 \mathrm{~cm}$ to $1.00 \mathrm{~cm}$. Average weight of bulb (g) was significantly influenced to the maximum in T12 (38.03g) whereas bulb of control treatment weighed 27.30g (Gowda et al., 2007, Bhandari et al., 2014 and Das et al., 2014). The Average diameter of pseudostem in other treatments ranged from 28.86 gto 37.03 g. Average bulb yield /plot was recorded $5.09 \mathrm{~kg}$ in control whereas in T12 it was $5.96 \mathrm{~kg}$. In other treatments it was recorded to vary between $5.14 \mathrm{~kg} /$ plot to 5.71 kg/ha (Singh et. al., 2008, Yogita et al., 2012, and Das et al., 2014) (Table 1).

Table.1 Summarized pooled data on various yield parameters recorded at the time of harvesting

\begin{tabular}{|c|c|c|c|c|c|}
\hline Treatments & \multicolumn{3}{|c|}{ Growth Parameters } & \multicolumn{2}{c|}{ Yield Parameters } \\
\hline & $\begin{array}{c}\text { Plant } \\
\text { height } \\
\text { (cm) }\end{array}$ & $\begin{array}{c}\text { No. of } \\
\text { leaves }\end{array}$ & $\begin{array}{c}\text { Diameter of } \\
\text { pseudo- } \\
\text { stem(cm) }\end{array}$ & $\begin{array}{c}\text { Wt. of } \\
\text { bulb/plant } \\
\text { (g) }\end{array}$ & $\begin{array}{c}\text { Yield per plot } \\
\text { (kg) }\end{array}$ \\
\hline $\mathbf{T}_{\mathbf{0}}$ & 73.36 & 6.30 & 0.66 & 27.30 & 5.09 \\
\hline $\mathbf{T}_{\mathbf{1}}$ & 74.46 & 6.76 & 0.76 & 29.40 & 5.21 \\
\hline $\mathbf{T}_{\mathbf{2}}$ & 75.90 & 7.46 & 0.83 & 30.73 & 5.35 \\
\hline $\mathbf{T}_{\mathbf{3}}$ & 73.83 & 6.40 & 0.70 & 28.86 & 5.14 \\
\hline $\mathbf{T}_{\mathbf{4}}$ & 75.53 & 6.93 & 0.83 & 30.13 & 5.28 \\
\hline $\mathbf{T}_{\mathbf{5}}$ & 74.16 & 6.46 & 0.76 & 29.13 & 5.15 \\
\hline $\mathbf{T}_{\mathbf{6}}$ & 74.70 & 6.93 & 0.80 & 29.80 & 5.21 \\
\hline $\mathbf{T}_{\mathbf{7}}$ & 78.20 & 8.36 & 0.96 & 33.03 & 5.45 \\
\hline $\mathbf{T}_{\mathbf{8}}$ & 78.93 & 9.56 & 1.00 & 37.03 & 5.71 \\
\hline $\mathbf{T}_{\mathbf{9}}$ & 76.13 & 7.80 & 0.76 & 31.16 & 5.30 \\
\hline $\mathbf{T}_{\mathbf{1 0}}$ & 78.10 & 8.90 & 0.93 & 35.73 & 5.66 \\
\hline $\mathbf{T}_{\mathbf{1 1}}$ & 76.60 & 7.96 & 0.80 & 31.56 & 5.36 \\
\hline $\mathbf{T}_{\mathbf{1 2}}$ & 79.83 & 9.86 & 1.13 & 38.03 & 5.96 \\
\hline $\mathbf{T}_{\mathbf{1 3}}$ & 77.83 & 8.53 & 0.90 & 32.43 & 5.56 \\
\hline $\mathbf{T}_{\mathbf{1 4}}$ & 77.23 & 8.10 & 0.83 & 32.03 & 5.43 \\
\hline $\mathbf{C D}$ & 0.47 & 0.54 & 0.21 & 0.81 & 0.07 \\
\hline
\end{tabular}

Data on economics of various treatments revealed that the plot treated with the combination of 3 biofertilizers each @ $8 \mathrm{~kg}$ /ha $\left(\mathrm{T}_{12}\right)$ was found to be the best amongst all. 
The combination of Azotobactor @ 6kg/ha, PSB and VAM each @ 8kg/ha $\left(\mathrm{T}_{8}\right)$ stand with net profit of 4.304 lakh and C:B ratio 1: 3.06, was found to be the next best followed by the combination of Azotobactor @ 6kg/ha, PSB $@ 8 \mathrm{~kg} / \mathrm{ha}$ and VAM @6kg/ha $\left(\mathrm{T}_{10}\right)$ gave net profit of 4.257 lakh with $\mathrm{C}: \mathrm{B}$ ratio of 1: 3.03 . $\mathrm{T}_{12}$ accounted for a net profit of nearly Rs 4.551 lakh and a widest cost: benefit ratio 1 : 3.23 .

\section{Acknowledgement}

We are thankful to Head, Department of Horticulture C.S.A. University of Agriculture and Technology, Kanpur for providing layout, biofertilizers and Azotobacter culture etc. and technical support for the trial.

\section{References}

Adegoke, G. O., V. M. Kumar, A. G. Gopalakrishna, M. C. Varadaraj, K.S ambaiah and B. R. Lokesh 1998. Antioxidant and Lipid oxidation in foods.A critical appraisal. Journal Food science Technology. 35: 283-298.

Bhandari, S. A., K. S. Patel and D. S. Nehete. 2014. Effect of integrated nutrient management on growth, yield and quality of garlic (Allium sativum L.) cv. Gujarat Garlic-3. Asian Journal of Horticulture. 7(1): 48-51.

Bhat, A., M. Gupta, M. A. Ganai, R. A. Ahanger and H. A.Bhat2013.Yield, soil health and nutrient utilization of field pea (Pisum sativum 1.) as affected by phosphorus and bio-fertilizers under subtropical conditions of Jammu. International Journal of Modern Plant \& Animal Sciences 1(1): 1-8.

Das, S., M. Chanchan and J. K.Hore2014.Effect of inorganic and bio-fertilizer on growth and yield of garlic (Allium sativum L.). Agricultural and Horticultural Sciences. 2(4): 42.
Dorais, M., A. P.Papadoulos and A.Gosselin2001.Greenhouse tomato fruit quality. Horticultural Review.26: 262-319.

Gaiki, U. R., N. D. Jogdande, S. R. Dalal, D. R. Nandre and S. M. Ghawade2006. Effect of biofertilizers under reduced doses of inorganic fertilizers on growth and yield of garlic. Plant Archives, 6(1):367-368.

Gowda, M. C., M. Vijayakumar and A. P. M.Gowda2007.Influence of integrated nutrient management on growth, yield and quality of garlic (Allium sativum L.) cv. G-282. Crop Research Hisar.33(1/3):144-147.

Shembekar, R. Z., M. S. Kore, N. K. Chopde, O. D. Kuchanwar, S. S. Pillewan and S. B. Godse 2006. Nutrient management in garlic (Allium sativum L.). J. Soil Crops, 16(2): 465-468.

Pradhan, G., E. Florescue , M. Mihalache, M. Vistarion, E. Baciu, N. Boravbantu and T. Tudor 1977. Quoted by T.K. Bose. Vegetable Crops in India.pp. 583. Nocolae Balccesu Hort., 17:7-15.

Satish, G. and J. Rajangam2011. Aromatic compounds of spices and condiments. Agrobios., 10(7): 56-57.

Singh, A. P., O. Singh, V. Singh and S. Kumar. 2008. Effect of integrated use of FYM and inorganic fertilizers on yield and uptake of nutrients by onion. Progressive Agriculture. 8(2): 265-267.

Singh, V., K. C. Sharma, H. R. Sharma 2017. Effect of Bio-Inoculants and Graded Level of Fertilizers on Nutrient Uptake in Garlic. International Journal of Current Microbiology and Applied Sciences. 6(5):1200-1209.

Talware, P., N. K. Gupta and S.Dubey 2012.Effect of organic, inorganic and bio-fertilizers on growth and productivity of garlic (Allium sativum) cv. G- 323.Crop Research (Hisar).43(1/2/3): 89-97. 
Verma, L. N. 1993. Organics in soil health and crop production, Ed. (Thampan, P.K.). Tree Crop Development Foundation, Cochin .151-184. chemical and bio-fertilizers on quality of onion. Hort. Flora Research Spectrum. 1(4): 367-370.

Yogita and R. B. Ram. 2012. Effect of

\section{How to cite this article:}

Chandra Bhushan, Anil Kumar Yadav, Hemant Kumar Gangwar, Brajesh Kumar, Sunil Kumar Katiyar and Nitin Vikram. 2020. Effect of Bio-fertilizers on Growth and Yield of Garlic (Allium sativum Linn.) Int.J.Curr.Microbiol.App.Sci. 9(11): 739-743.

doi: https://doi.org/10.20546/ijcmas.2020.911.088 